\title{
A MODEL FOR SEDIMENTATION BY TIDEWATER
}

\section{GLACIERS}

\author{
by \\ Ross D. Powell \\ (Institute of Polar Studies and Department of Geology and Mineralogy, The Ohio State \\ University, Columbus, Ohio 43210, U.S.A.)
}

\section{ABSTRACT}

Sampling of sediment from the fjord floor in front of tidewater glaciers in Glacier Bay, Alaska, has provided information about processes in this restricted glacimarine (Dreimanis 1979) setting. Sediment sampling, in conjunction with oceanographic and glacial dynamics data, has also enabled the discrimination of sediment types and their facies associations. Deposits are strongly controlled by: sea-water characteristics, position and sediment discharge of melt-water streams, iceberg calving, and rate of glacierfront retreat.

Five distinct facies associations have been found to reflect glacier-fjord regimes. The facies associations and ice-fjord conditions responsible for them form the basis for constructing a preliminary model for glacimarine sedimentation by tidewater glaciers. The model can be used to predict (i) rapid retreat of an actively calving ice front, ( $i i)$ slow retreat or stabilization of a calving ice front at a channe constriction, (iii) stabilization of a melting (very rarely calving) ice front when the glacier base is near tidewater elevation, and (iv) large outwash del ta progradation into a fjord when the ice front retreats onto land. This model can be used to interpret facies associations found in a stratigraphic record.

\section{INTRODUCTION}

This study presents results from data collected by grab sampling and gravity coring in front of 11 glaciers in Glacier Bay National Monument, south-east Alaska. Five distinct facies associations reflecting different glacierfjord regimes have been distinguished, and formulated into a sedimentary facies model based on processes operating in a temperate tidewater glacimarine (Dreimanis 1979) setting.

\section{GLACIMARINE LITHOFACIES} below.

The major lithofacies are described

Morainal bank lithofacies is composed of a chaotic mixture of diamicton, grave1, rubble, and sand built into a large ice-contact bank during slow glacier-front retreat. Sediment is contributed from calving icebergs, en- and subglacial melt-out, and subglacial streams. Small morainal banks (push moraines) of gravel, rubble, and diamicton are formed by very minor winter advances of an ice front. Such deposits are preserved and are mainly identifiable in a regime where the ice front undergoes rapid summer retreat. Isolated pites of gravel and mbble are contributed to mud and reworked diamicton on the fjord floor from bergs calving from a rapidly retreating glacier front and, to a lesser degree, from bergs overturning in the more distant iceberg zone.

Dicmicton 1 ithofacies may be produced by several processes: subglacial and melt-out till deposition, sediment gravity flows from fjord floor "highs", and the mixing of silt and clay (from melt-water streams) and coarse-grained sediment (from numerous dirty icebergs). When icebergs are less numerous and cleaner, the silt and clay contain a lower proportion of coarsegrained sediments and an iceberg-zone mud lithofacies is produced. When a glacier front is terrestrial, and not contributing icebergs with a coarse-grained sediment fraction to the sea, a marine-outwash mud lithofacies is produced. Underflows may be generated from subglacial melt-water discharges if sediment loads are sufficiently high; they carry away sand and form thin laminae within mud which is deposited during periods of low stream discharge when the underflows are suppressed. The underflow will gradually dissipate as momentum and density decrease, finally rising buoyantly to become an interflow or overflow. Laminae of fine- to medium-grained sand ( $\mathrm{mm}$ thick), having sharp top and bottom contacts, are produced in a rhythmic layering with mud when the site is influenced by underflows. Thinner laminae, one or two grains thick, of very fine-grained sand and silt are deposited from interflows and underflows distant from the efflux. The resultant lithofacies is Zaminated sand and mud. sediment gravity flows and turbidity current channels are commonly produced from morainal banks and large outwash deltas. Deltas form as melt-water streams enter the sea in both lateral and central positions from the ice face. Central deztas may form under both fast and slow rates of ice retreat, and can produce esker-type forms when ice retreats rapidly. The largest lateral del tas build across the ice face and down-fjord when the base of the ice is near tidewater. When the glacier front has entirely retreated from the sea, outwash deltaic and braided stream lithofacies are produced.

*Present address: Department of Geology, Northern I1linois University, Dekalb, Illinois 60115, U.S.A. 
Large tidal ranges and high mud concentrations with in the sea are conducive to tidatflat formation (some are ephemeral, being destroyed by winter erosion).

The sediment in different glaciers in Glacier Bay is derived predominantly from acidic intrusives and metasediments and is generaliy similar mineralogically. The degree of comminution by glaciers is therefore assumed constant so that particle-size distributions are primarily a function of depositional processes and comparable between different glaciers.

Some of the lithofacies, such as diamicton, iceberg-zone mud, and laminated sand and mud, are common to three or more facies associations. Such facies associations are defined by $7 i$ thofacies combinations and their relationships. other lithofacies such as morainal banks, marine outwash mud, and tidal-flat mud are unique, and therefore define a facies association.

FJORD GLACIMARINE FACIES ASSOCIATIONS

Facies Association I: Facies of rapidly

retreating tidewater glaciers with ice
fronts actively calving in deep water
(Fig. 1)

The following description of facies associations is based on findings from Muir Glacier and inferences made from other glaciers studied. Facies deposited close to such an ice front consist of reworked subglacial ti11, subglacial stream gravel and sand, scattered and dumped coarse-grained supraglacial debris, and low icepush moraines. Farther away from the ice front, iceberg-zone mud accumulates and intertongues with the interbedded sand and mud lithofacies.

Ice calves actively during rapid summer ice retreat, but markedly less actively during winter. Water is deep (hundreds of meters), so wind-generated water waves will not influence sediment on the fjord floor, and icebergs calving from above sea-level and associated turbulence will not influence the fjard floor. Subglacial till is exposed on the fjord floor and may be reworked by tidal currents, stream underflows, and sediment gravity flows. Therefore, a newly exposed fjord floor has a thin gravel and sand layer due to minor reworking of compacted subglacial till. A small amount of glacial basal debris may melt out at the fjord floor against the ice face.

If substantial supraglacial debris is dumped off the ice as it calves, it will remain as piles of rubble and gravel on the fjord floor. The area close to the ice face is a highly turbid brackish-water environment devoid of organisms except for many shrimp and rare polychaetes. Subglacial melt-water streams introduce gravel and sand into the marine environment directly at the base of the water column. If highly sediment-charged, they produce laminated sand and mud lithofacies. Gravel and sand may remain as an ice-moulded ridge (an esker-type form), but large fans will not be produced because of the mobile ice front. . Mud of the iceberg zone accumulates in the ice-proximal basin, but, if retreat is rapid, sufficient turbulence is produced with in the water column to maintain mud in suspension accompanied by transport away from the ice front. During winter months, when calving slows drastically, the ice front may remain in one position or even advance (meters or hundreds of meters). Stream activity decreases and finegrained sediment settles quietly out. Unlike the lacustrine environment, the more open system in a fjord may remove such clays. The most characteristic sediments are small subaqueous end moraines deposited against the ice face, approximately normal to the fjord walls. Sedi-

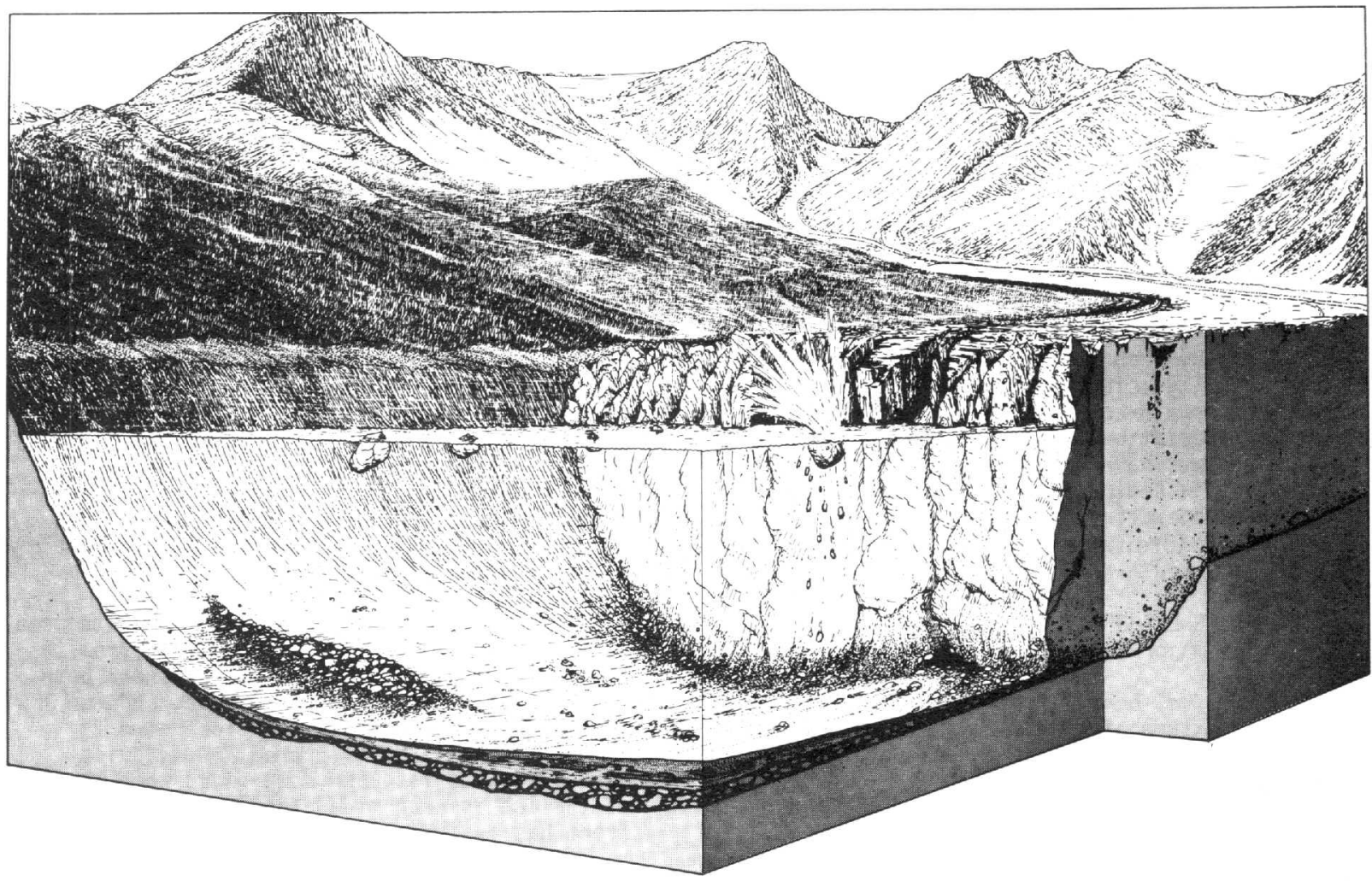

Fig.1. Rapidly retreating tidewater glacier actively calving in deep water. Sediment facies shown are Facies Association I. 
ment incorporated in the ridges can originate in two ways: (i) melting of debris-rich basal ice by the water, or ( $i i)$ ice-push. The former may be important, but the rate of ice melting decreases from summer because of the decrease $\left(\approx 2{ }^{\circ} \mathrm{C}\right.$ for Muir Inlet) in bottom sea-water temperature. The result would be ridges similar in morphology to De Geer, washboard or crossvalley moraines.

Facies Association II: Facies of a slowly retreating tidewater glacier with ice front actively calving predominantly in shallow water (Fig. 2)

Retreat of an ice front decreases dramatically or may virtually cease at a channel constriction created by fjord-floor highs or wall protuberance, but calving can still continue at a relatively rapid rate. The resulting Facies Association II consists of ice-proximal coarsegrained morainal banks with ice-contact lateral and central fan deltas. Subaqueous sedimentgravity flows are common down the bank foreslope producing intertonguing sand layers within iceberg-zone mud depositéd more distally (e.g. Riggs, Grand Pacific, Margerie, Lamplugh, and Johns Hopkins glaciers).

Under such conditions, subaqueous morainal

banks in an ice-contact position are constructed af coarse-grained clastic sediment (Fig. 2). Sediment is contributed by melting out of basal and englacial debris and also by dumping of supraglacial debris as ice calves. Diamicton textures may be present from the melting-out process, especially when the bank is initially constructed in relatively deep water. As the bank builds into shallower water it comes under a higher energy regime created by calving events, tida 1 currents, and, perhaps, windgenerated water waves. This yields a lag of sand- to cobble-size sediment on the bank surface with rare pockets of diamicton texture in depressions, which may form from subaqueous sediment gravity flows such as debris flows and sTumps. Rarely, a diamicton is formed by mud from overflows from melt-water streams, combined with ice-rafted coarser material dropped from numerous bergs floating in front of the ice face. Subglacial till may be plastered on to the bank during minor winter ice-front advances. Subglacial subaqueous streams discharge laterally and centrally from the ice face and build deltas or fans on the bank surface. Lateral deltas build along the ice face and down fjord walls. Stream discharges and sediment concentrations are occasionally high enough to form underflows that transport sand into the pro-deltaic environment. Gravel is rolled down the fore-slope of deltas built by such high discharge streams.

Other lateral deltas are formed under lower energy conditions by the accumulation of mud on the fore-slope due to flocculation and sedimentation from the turbid overflow plumes produced as the stream enters the sea-water and remains buoyantly at the sea surface. Rarely, interflows may form if the sea-water has a marked pycnocline. More often, interflows are produced by the sinking of the turbid overflow of an ebb tide beneath the inflowing water of the following flood tide. When deltas of this type are adjacent to an ice front with supraglacial debris, a diamicton is produced by coarsergrained material contributed from icebergs. Occasionally, central subglacial streams have sufficiently high sediment concentrations to produce underflows that transport sand away from the ice front while gravel is left near it. Structureless sand and inter-laminated sand and mud lithofacies are produced.

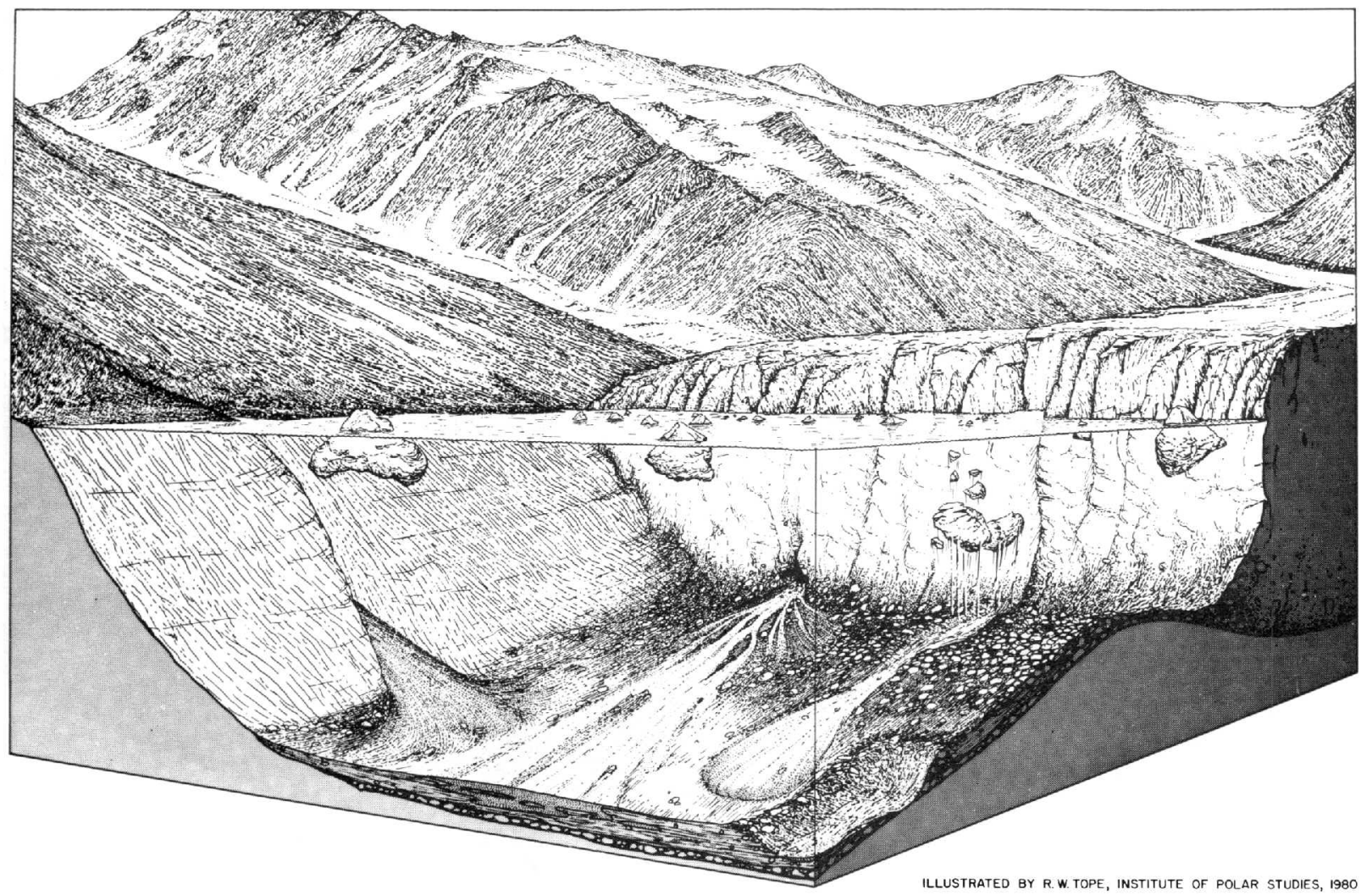

Fig.2. Slowly retreating tidewater glacier actively calving in shallow water. Sediment facies shown are Facies Association II. 
These central streams can build ice-contact subaqueous fans on the bank surface and the surface of the fan may eventually become intertidal if the stream stays in one position for several melt-water seasons and melts a channel vertically up the ice face. Often, however, the position of a subglacial-stream discharge changes from one melt-water season to the next and a series of small overlapping fans may form along the bank in front of the ice.

Slumping and sediment gravity flows are common down the bank fore-slope (angles $\leq 20^{\circ}$ ). Sloping fjord walls direct slumps into a central trough which is elongated and parallel to the walls, and extends farther away from the ice face as turbidity-current channels develop from the slumps. Slumping may originate from high sedimentation rates and consequent slope oversteepening, or from calving events when bergs reach or come very close to the bank surface. Sediment is finer-grained down the fore-slope.

In more distant areas from the ice front, iceberg-zone mud accumulates at a rapid rate $\left(\geq 4.4 \mathrm{~m} \mathrm{a}^{-1}\right)$ in the ice-proximal fjord-floor basin. This mud laps onto the morainal bank, and pro-bank sand layers (turbidites or underflow deposits) intertongue with the iceberg-zone mud facies. The thickness of the mud on the floor of a fjord basin is determined by the length of time that the ice remains at the head of the basin and by the volume of the basin. Most mud is deposited in the ice-proximal basin whereas down-fjord basins receive much smaller amounts of mud. Therefore, each isolated bas in will have its own level of mud infill, unless it is full in which case mud is transported across the sill into the next basin by sediment-gravity flows.
Facies Association III: Facies deposited by a slowly retreating or advancing tidewater glacier rarely calving into shallow water (Fig. 3)

When ice fronts retreat or advance into shallow water they may end in a protected bay environment. Resulting Facies Association III consists of iceberg-zone mud deposited close to the ice front away from stream discharges and in more distant areas. Lateral streams dominate the environment close to the ice front, introducing gravel and sand over large fan deltas, and the sand intertongues with mud in more distant locations (e.g. McBride, Lituya, and North Crilton qlaciers).

If this protected embayment occurs at the head of a fjord and the glacier stabilizes or perhaps stagnates, then ice loss by surface melting may be of similar or greater magnitude than calving. This is the opposite situation to that described previously for other facies associations.

Very large lateral fan deltas build along the ice face and down-fjord. A glacier can then override these deposits and advance. Dis-

charges from the deltas and from subaqueous subglacial streams introduce sand-size material to the mud facies. Structureless fine- to coarsegrained sand beds are produced near subaqueous discharges. This sand changes laterally into muddy sand and finally into interlaminated sand and mud. This latter interlaminated sediment is also common in pro-deltaic areas of lateral discharges and gravel rolls down the lateral delta fore-slopes.

Farther away from the ice front, the flows introduce occasional laminae of fine-grained sand. Thicker sand layers in more distal posit-

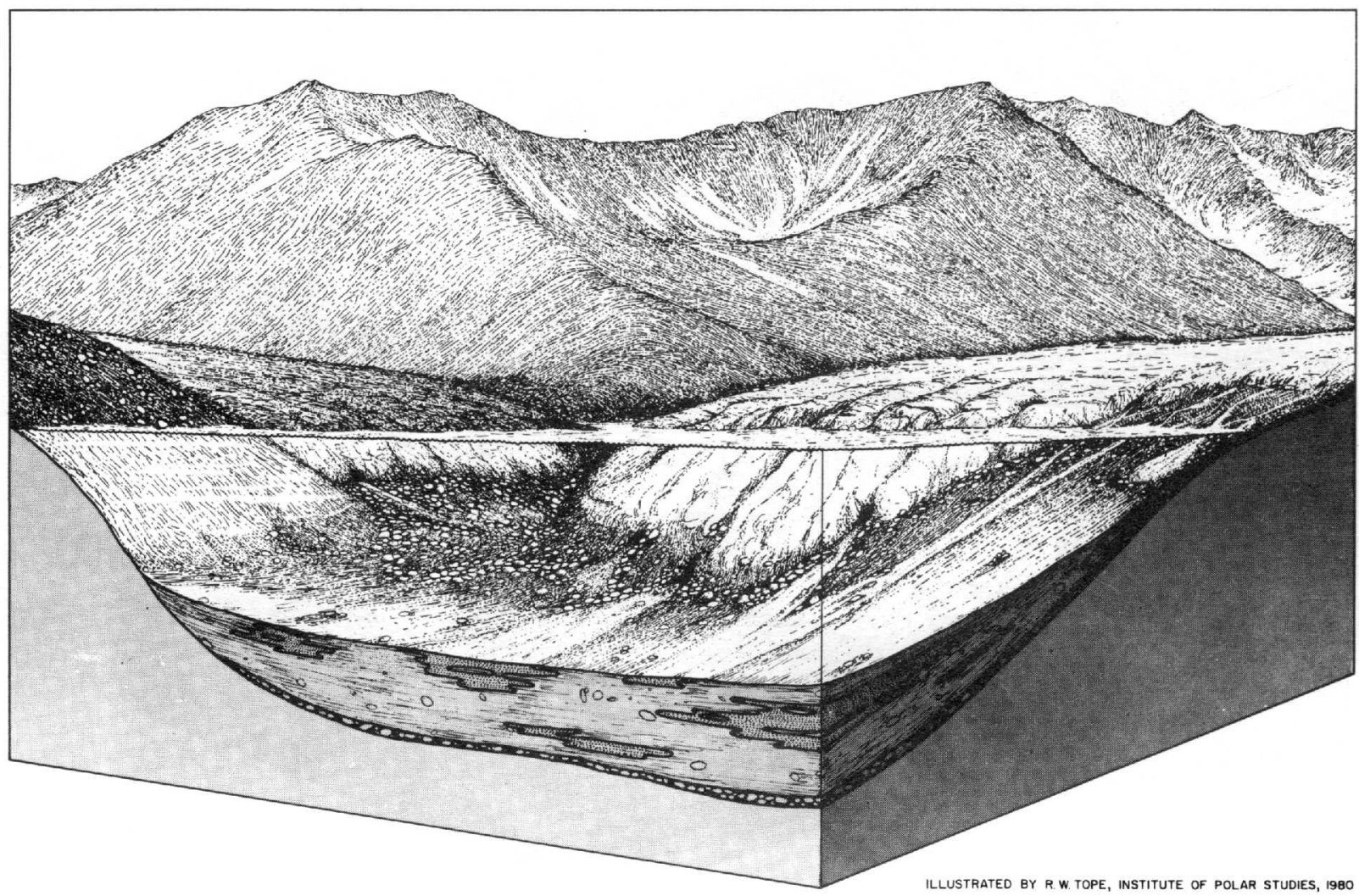

Fig.3. Slowly retreating tidewater glacier rarely calving in shallow water. Sediment facies shown are Facies Association III. 
ions exhibit normal grading and resemble Bouma sequences of unit $A$ turbidites. X-radiographs of distal mud show interflow deposits of thin laminae of very fine-grained sand and silt. Temporal variations in particle size, due to fluctuations in discharge and sediment loads of melt-water streams from where the plumes originate, produce these laminae. Iceberg-zone mud has varying amounts of ice-rafted debris (IRD) with generally less than $10 \%$ pebble-sized clasts, especially in more distal fjord floor basins. Any supraglacial debris is dumped in piles on the fjord floor mud close to the ice front. If ice loss is dominated by surface melting rather than calving and the ice is clean of debris (Reid Glacier), then very little IRD may be produced and better-sorted mud accumulates. If the ice has large volumes of supraglacial debris (Carroll Glacier), a diamicton texture with clasts comprising at least $10 \%$ of the sediment is produced in areas away from stream discharges. These conditions of dominance of melting rather than calving and large volumes of supraglacial debris would the most favorable of all environments described for production of debris flows from the ice, al though no large flows were observed.

In protected basins with shallow entrance sills, black layers are produced, possibly on a seasonal basis, due to the occurrence of periodic anaerobic conditions. Generally, however, black layers and patches occur irregularly with depth but are often associated with turbidite layers.

\section{Facies Association IV: Facies of a turbid}

\section{outwash fjord (Fig. 4}

When the front of a gTacier retreats from the sea and becomes terrestrial, large outwash delta deposits build up and prograde out into the fjord. The resulting Facies Association IV consists of coarse-grained fluvial deposits on the delta surface and has sand on its foreslope. This sand intertongues with marine outwash mud (glacial flour silt and clay with very minor coarse-grained component) in areas more distant from the ice front.

The outwash delta progrades out into the fjord producing similar facies to the deltas formed in Facies Associations II and III. If high peak discharges occur and large quantities of fine-grained sediment are available on the delta plain for fluvial transport, continuous underflows may be produced from the melt-water stream discharges as they enter fjord water during high summer flow. As the del ta progrades, coarse-grained glacifluvial sediment on the delta surface is deposited unconformably over the delta foreset sands and gravels and signifies the late stages of glaciation in an area.

Mud is the dominant sediment type in more distal areas. Very little IRD is present with in the mud as only very few and small bergs are introduced via melt-water streams over the outwash delta. The resultant sediment is marine outwash mud which consists of glacial flour silt and clay from glacial melt-water streams. This marine outwash mud may be cut by channels (e.g. Queen and Rendu inlets) floored wi th rhythmically bedded silt and very fine-grained sand, interpreted as turbidites. The erosionaldepositional turbidity current channels are cut by the underflows produced by melt-water streams discharging from the outwash delta, or from slumps on the delta fore-slope.

Facies Association V: Facies of shallow-water environments distant from ice fronts During deposition of Facies Associations I to IV, tidal flats commonly develop in shallow water. Facies Association V consists of tidalflat muds and braided stream and beach sands

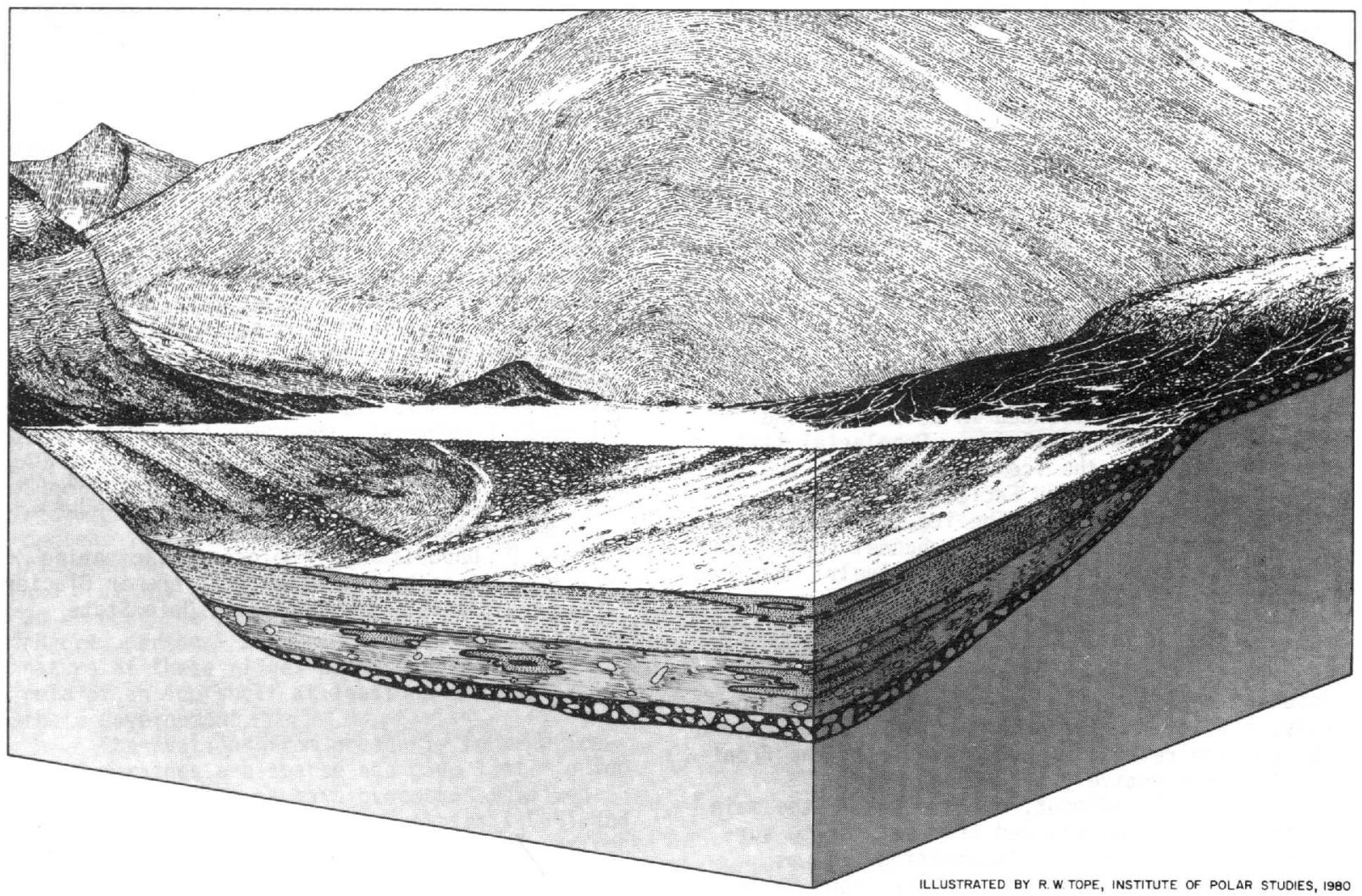

Fig.4. Turbid outwash fjord where the ice front is terrestrial. Sediment facies shown are Facies Association IV. 


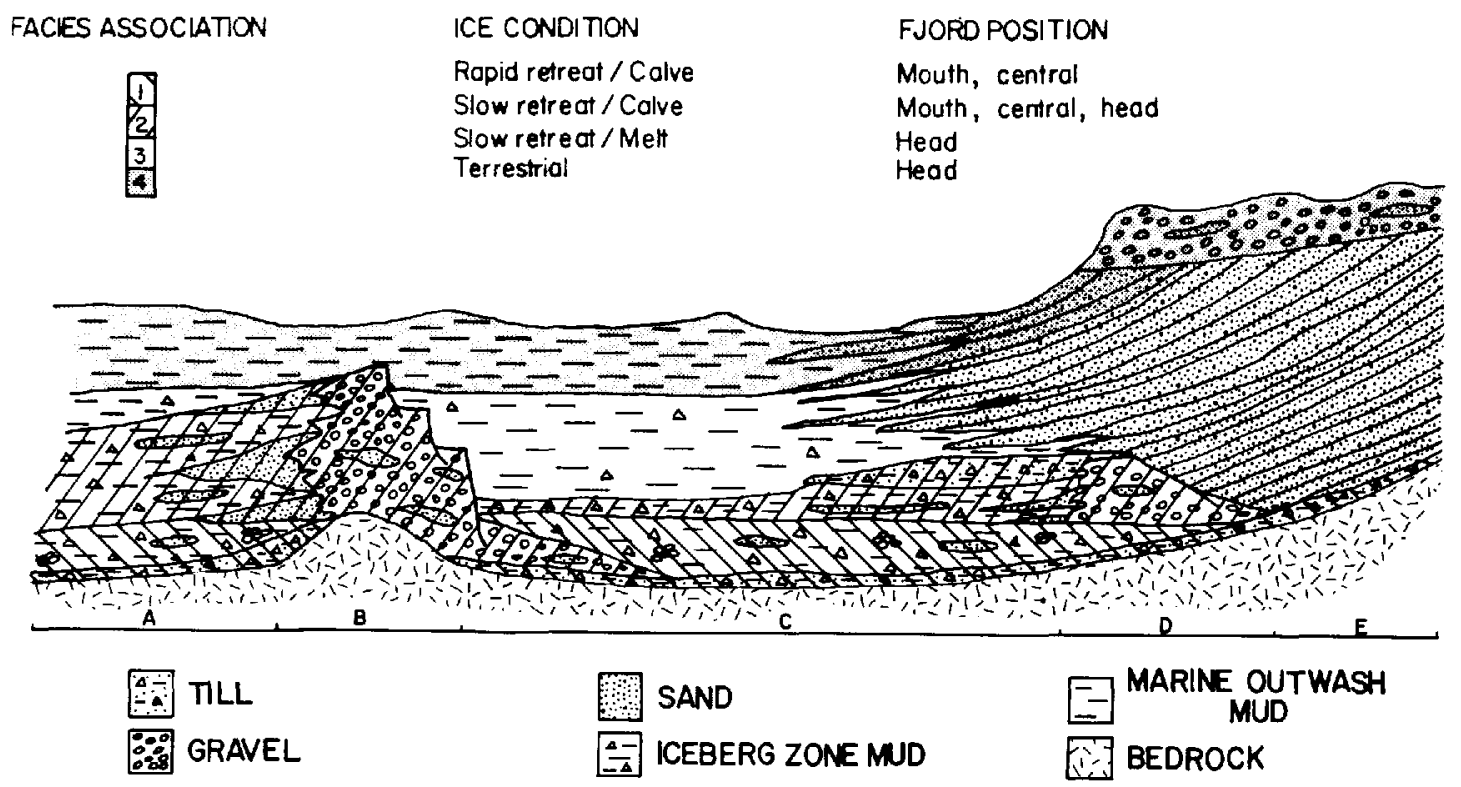

Fig.5. Hypothetical section of glacimarine sediment showing general sedimentary facies and facies associations.

(e.g. Dundas Creek sections and Dundas Bay tidal flats).

Tidal flats develop on coarse-grained clastic morainal sediment or glacimarine diamicton as the land is uplifted isostatically during ice retreat. If a site is distant from the ice, the tidal environment has abundant life that leaves its remains in the mud. Icebergs may ground on the flats during ebb tide and contribute coarser-grained clastic sediment. Farther offshore, diamicton accumulates and may contain barnacles attached to clasts dropped from temporarily stranded icebergs (e.g. at. Ptarmigan Creek). Winter sea-ice may also freeze-in beach pebbles which are rafted away during break-up.

With continued isostatic recovery, the flats may become subaerially exposed, and shrubs and, later, trees will become established. If the ice readvances, this land will aga in be drowned by the sea, the forest will die, and stumps will remain to be buried during renewed mud depasition (e.g. Dundas Bay).

\section{INTERPRETATION OF A HYPOTHETICAL SECTION}

A hypothetical sediment section has been drawn (Fig. 5) using the model above. At interval $A$, the ice front ended in deep water and retreated rapidly by calving. Subglacial till deposited beneath the ice was exposed to the sea and slightly reworked. Facies Association I sediment was deposited. The ice front retreated to $B$ where it was slowed by a channel constriction but the front still calved actively. Facies Association II was deposited with build-up of a morainal bank. Eventually the ice front retreated from the constriction into deeper water (C). Ice retreat was again rapid and Facies Association I was once more deposited. Eventually, the ice front reached the head of the fjord (D) and ice retreat slowed. At first, the front still calved actively to produce Facies Association II sediment, but eventually the main method of ice loss changed from calving to surface melting and Facies Association III was deposited. Finally, at $E$, the ice front became completely terrestrial and a large outwash delta built out over all previous facies, and Facies Association IV sediment accumulated.

\section{CONCLUSION}

This paper presents a tentative sedimentation model using lithofacies produced under a tidewater glacimarine regime which can be used to interpret older glacimarine sequences by application of Walthers' Law. It should also be usefut for predicting conditions and deposits in other glacimarine regimes. Not all lithofacies or facies associations described will be present, especially in ancient sequences, and some may be present by themselves. Companion papers presenting basic data and more detailed field descriptions are in preparation (also see Powell, unpublished).

\section{ACKNOWLEDGEMENTS}

This study was carried out at the Institute of Polar Studies (IPS), Ohio State University (OSU), under the guidance of Or Ken Staniey. The author wishes to thank US Geological Survey scientists, Drs P. Carlson, B. Molnia, and A. Post, for information and the National Park Service for logistics. Funding was provided by IPS, the Arctic Institute of North America, the Geological Society of America, and Sigma $X_{i}$ and the Orton Ha7l Fund of OSU.

\section{REFERENCES}

Dreimanis A 1979 Commission on genes is and 1 ithology of Quaternary deposits (INQUA). Boreas 8(2): 254

Powell R D Unpublished. Holocene glacimarine deposition by tidewater glaciers in Glacier Bay, Alaska. (Ph D thesis, Ohio State University, 1980) 